\title{
FASILITAS UNTUK PEDESTRIAN ANAK-ANAK DALAM PERSIAPAN SISTEM ZONASI PPDB DI INDONESIA.
}

\author{
Erna Winansih ${ }^{1}$, Dina Poerwoningsih ${ }^{1 *}$, Razqyan Mas Bimatyugra Jati ${ }^{1}$ \\ 1 Program Studi Arsitektur, Universitas Merdeka Malang \\ *dina.poerwoningsih@unmer.ac.id
}

\begin{abstract}
ABSTRAK
Sistem zonasi atau pengaturan proses penerimaan siswa baru sesuai wilayah tempat tinggal tampaknya menjadi pilihan yang dipertahankan dalam beberapa tahun mendatang. Dampak dari pemberlakuan sistem tersebut adalah jarak tempuh sekolah yang semakin dekat, sehingga dapat berkontribusi pula pada berkurangnya kepadatan transportasi kota. Sekolah yang berada dalam radius permukiman perkotaan memiliki tantangan tersendiri. Alasan pemerintah dalam keputusan sistem Zonasi salah satunya adalah memberikan akomodasi siswa prestasi dan tidak mampu, semestinya bisa didukung oleh upaya peningkatan sarana prasarana siswa sekolah khususnya pada tingkat pendidikan dasar dan menengah. Kebijakan sistem zonasi dapat menjadi faktor pendukung dalam rangka mewujudkan Kota Ramah Anak (Children Friendly Cities atau CFC). Salah satunya dengan memfasilitasi kebutuhan pejalan kaki anak-anak (pedestrian way for kids) di lingkungan perkotaan. Tulisan ini bermaksud memaparkan beberapa gagasan pedestrian way yang ramah anak di lingkungan perkotaan. Metode yang digunakan adalah mereview beberapa referensi peraturan, pengalaman praktis dan jurnal penelitian yang terkait dengan pedestrian way for kids. Permukiman perkotaan yang berada pada radius sekolah di pusat kota perlu mendapatkan perhatian khusus dalam pengaturan dan penyelenggaraan fasilitas bagi pedestrian anak-anak yang menjadi sasaran siswa sekolah. Tulisan ini menekankan pembahasan pada dua atribut penting yang sesuai dengan kondisi di Indonesia yaitu: pertama adalah atribut ketersediaan ruang bagi pejalan kaki anak-anak serta kedua adalah atribut karakter bermain anak-anak.
\end{abstract}

Keywords: pejalan kaki anak-anak, pedestrian way for kids, sistem zonasi PPDB, kota ramah anak

\begin{abstract}
The regulation of zoning system as an admission process according to the area of residence seems to be a choice that is maintained in the coming years. The impact of the implementation of the system is the school distance that is getting closer, so that it can also contribute to the reduction in urban transportation density. Schools that are within the radius of urban settlements have their own challenges. One reason for the government in the decision of the Zoning system is that one of them is to provide accommodation for students who are not able to afford, and should be able to be supported by efforts to improve the infrastructure of school students, especially at primary and secondary education levels. Zoning system policies can be a supporting factor in realizing Child Friendly Cities (CFC). One of them is by facilitating the needs of pedestrian way for kids in urban environments. This paper intends to explain some ideas of child-friendly pedestrian way in an urban environment. The method used is to review some regulatory references, practical experience and research journals related to pedestrian way for kids. Urban settlements within the school radius in the city center need special attention in the arrangement and administration of facilities for children pedestrian who are targeted by school students. This paper emphasizes the discussion on two important attributes that are in accordance with the conditions in Indonesia, namely: first is the attribute of space availability for children pedestrians and second is the attribute of children's play characters.
\end{abstract}

Keywords: children pedestrian, pedestrian way for kids, PPDB zoning system, child friendly city 


\section{PENDAHULUAN}

Sistem zonasi atau pengaturan proses penerimaan siswa baru sesuai wilayah tempat tinggal tampaknya menjadi pilihan yang dipertahankan dalam beberapa tahun mendatang. Kebijakan yang dikuatkan dalam Permendikbud Nomor 44 Tahun 2019 tentang Penerimaan Peserta Didik Baru (PPDB)ini dilaksanakan dengan mendasarkan beberapa alasan yaitu (1) Akomodasi siswa prestasi dan tidak mampu, (2) Memberikan fleksibilitas pada daerah, (3) Pemerataan kuantitas dan kualitas guru. Kebutuhan akan sarana prasarana terutama pedestrian way bagi siswa sekolah di lingkungan perkotaan sangat diperlukan. Pedestrian way di lingkungan perkotaan tidak hanya di area pusat kota namun tersebar dalam beberapa lapisan skala lingkungan yang berbeda.

Berlakunya sistem zonasi menjadikan pedestrian way sarana penting bagi siswa untuk mengakses sekolah yang akan dilaluinya selama sekian tahun bersekolah. Menurut data UNICEF (2012) lebih dari satu miliar anak sekarang tinggal di daerah perkotaan di seluruh dunia. Pada tahun 2030, hingga 60\% dari populasi global diproyeksikan untuk hidup di perkotaan, dan hingga 60\% dari penduduk kota tersebut akan berusia di bawah delapan belas tahun (UNICEF, 2018). Oleh karenanya kota semestinya menjadi seting aktifitas yang mendukung tumbuh berkembangnya anakanak perkotaan yang sehat. UNICEF (2018) dan Christianet (2015) juga menyatakan tantangan kota yang ramah anak (Children Friendly Cities) termasuk di dalamnya adalah polusi suara dan udara, gaya hidup "malas bergerak", bahaya lalu lintas, kejahatan, isolasi sosial dan terputusnya hubungan dengan alam. Tantangan lain diperburuk oleh situasi kemiskinan dan ketidaksetaraan (UNICEF, 2012). Tantangan lain juga terjadi pada masyarakat negara berpenghasilan tinggi dengan anak-anak yang diprediksi hidup kurang sehat daripada orang tua mereka. (UNICEF, 2012; Christianet, 2015; UNICEF, 2018)

\section{METODE}

Tulisan ini dimaksudkan untuk mendeskripsikan aspek-aspek rekayasa teknis dan desain keruangan pada fasilitas pejalan kaki anak-anak. Pemaparan ini dipandang perlu untuk menegaskan pentingnya kesiapan infrastruktur dan prasarana jalan dalam menyikapi peningkatan intensitas perilaku pedestrian pada masa sistem zonasi diberlakukan. Secara umum pembahasan ini sangat terkait dengan upaya mewujudkan kota ramah anak.

Peraturan Menteri Pekerjaan Umum Nomor 03/PRT/M/2014 tentang Pedoman Perencanaan, Penyediaan, dan Pemanfaatan Prasarana dan Sarana Jaringan Pejalan Kaki di Kawasan Perkotaan. Dalam pasal 6 menyebutkan tentang kriteria prasarana dan sarana jaringan pejalan kaki yang terdiri atas: a. karakteristik pejalan kaki; b. karakteristik lingkungan; dan c. keterkaitan antar kegiatan dan moda transportasi lainnya serta jenis penggunaan lahan atau kegiatan. Mendasarkan pada kriteria tersebut tulisan ini menekankan pembahasan pada dua atribut penting yaitu: pertama adalah atribut ketersediaan ruang bagi pejalan kaki anak-anak serta kedua adalah atribut karakter bermain anak-anak. Pembahasan dilakukan secara deskriptif dari berbagai referensi dan jurnal riset yang terkait. 


\section{PEMBAHASAN}

\section{Sistem Zonasi sebagai momentum perwujudan Kota Ramah Anak di Indonesia}

Pemberlakuan sistem zonasi pada sistem penerimaan siswa baru di Indonesia tidak bisa dilihat dari aspek pelaksanaan pendidikan semata. Sistem tersebut berdampak luas pada segenap aspek kehidupan masyarakat baik secara sosial, ekonomi dan ekologi. Beberapa pemerintah kota terutama di kota-kota besar menyambut baik dan meyakini sistem zonasi akan banyak membawa dampak positif di sektor kehidupan perkotaan. Beberapa diantaranya meyakini bahwa sistem zonasi dalam Penerimaan Peserta Didik Baru (PPDB) akan memermudah para orang tua mencarikan sekolah di dekat tempat tinggal, sistem zonasi dipandang mampu mengurangi angka kemacetan di jalan raya terutama di pagi dan sore hari, sistem zonasi akan mengurangi biaya transportasi. Sistem Penerimaan Peserta Didik Baru (PPDB) berdasarkan zonasi berpotensi memberikan akses dan keadilan terhadap pendidikan bagi semua kalangan masyarakat. Pemerintah dan sekolah berperan dalam memastikan semua anak mendapat pendidikan dengan memerhatikan anak harus masuk ke sekolah terdekat dari rumahnya. (Mungkasa, 2017; Brown C. et al, 2019)

\section{Kota Ramah Anak identik dengan prasarana jalan yang walkable bagi anak.}

Kota ramah anak (Children Friendly Cities atau CFC) adalah kota atau komunitas atau sistem pemerintahan lokal apa pun yang berkomitmen untuk meningkatkan kehidupan anak-anak dalam yurisdiksi mereka dengan mewujudkan hak-hak mereka sebagaimana dinyatakan dalam Konvensi PBB tentang Hak-hak Anak. Dalam praktiknya komitmen tersebut dilaksanakan melalui upayaupaya mengintegrasikan aspirasi kebutuhan, prioritas, dan hak-hak anak ke dalam kebijakan, program, dan keputusan publik. Melalui konvensi PBB tersebut secara implisit menyatakan beberapa kriteria fasilitas atau tempat bagi anak-anak. Kriteria tersebut adalah bahwa anak-anak dapat hidup di lingkungan yang aman dan bersih dengan akses ke ruang hijau, juga bahwa anakanak dapat memiliki tempat untuk bermain dan bertumbuh bersama teman-teman sebayanya. (UNHR, 1990; Brown C. et al, 2019)

Sebagian kota-kota di dunia telah melakukan inisiasi dalam menjalankan amanah konvensi PBB tentang Hak-hak Anak tersebut. Kota-kota besar di negara maju telah menyusun langkahlangkah sistematis dalam rangka mengedukasi anak-anak dan orang tua untuk dapat berperilaku aman pada fasilitas pedestrian. Kota-kota tersebut menegakkan aspek keselamatan pejalan kaki yang mengharuskan anak-anak memiliki tempat yang aman untuk berjalan dan bermain, diawasi dengan benar ketika mereka berada di sekitar lalu lintas, dan belajar menggunakan kehati-hatian saat menyeberang jalan (SRTS Guide, 2015). Jakarta sebagai representasi kota yang ingin mewujudkan kota layak anak menyebutkan salah satu klaster/indikatornya adalah ketersediaan infrastruktur (sarana dan prasarana) di ruang publik yang ramah anak. Fasilitas pejalan kali termasuk elemen ruang publik (Mungkasa, 2017).

\section{Atribut ketersediaan ruang bagi pedestrian anak-anak}


Sistem Zonasi akan memberikan dampak pada intensitas penggunaan fasilitas pejalan kaki yang cukup tinggi di radius zona lingkungan sekolah tersebut. Oleh karenanya sangat diperlukan perhatian khusus tentang aspek teknis dari atribut ketersediaan ruang dan fasilitas pedestrian anakanak. Ketersediaan ruang dan fasilitas bagi pejalan kaki anak-anak dalam pembahasan ini mengacu kepada pengalaman dan praktek edukasi maupun penyusunan teknis dalam bentuk Panduan Prinsip Menerapkan Solusi Rute yang Aman menuju Sekolah. Ketersediaan ruang yang dimaksud tidaklah sekedar sarana prasarana yang sekedar ada dan tersebar begitu saja melainkan terbentuk dalam sebuah jaringan atau rute yang aman dan nyaman bagi anak-anak sepanjang berjalan menuju sekolah. Berikut adalah beberapa prinsip solusi teknis serta desain lingkungan binaan yang menyediakan rute aman bagi anak-anak saat mereka berjalan dan bersepeda ke sekolah. (SRTS Guide, 2015)

\section{a. Infrastruktur di dalam zona sekolah dan lingkungannya.}

Lingkungan fisik berupa infrastruktur menentukan seberapa kapasitas untuk mewadahi aktifitas siswa berjalan kaki atau bersepeda ke sekolah. Untuk berjalan dengan aman atau bersepeda ke sekolah di sepanjang jalan atau jalur yang terpisah, atau menyeberang jalan di sepanjang jalan, anak-anak membutuhkan fasilitas yang dirancang dengan baik, dibangun dengan baik, dirawat dengan baik, dan mudah diakses. Infrastruktur anak-anak sebagai bentuk pendekatan kebijakan perkotaan untuk mewujudkan "kota yang hidup" sebagaimana digagas oleh Arup (2017). Infrastruktur anak-anak adalah jaringan ruang, jalan, alam, dan intervensi yang mendukung kemampuan kota untuk menarik dan mempertahankan komunitas yang sehat dan berorientasi keluarga. Gagasan tersebut lebih dari sekedar taman bermain namun terintegrasi dalam jaringan kota, menjadi bagian dari ranah publik yang multifungsi di mana keluarga dan masyarakat dapat menikmati waktu bersama. (SRTS Guide, 2015)

Senada dengan gagasan infrastruktur anak-anak, Gehl Institute (2017) menetapkan 10 prinsip holistik yang mempromosikan perencanaan pembangunan sehat untuk anak-anak dan keluarga. Hasilnya adalah jaringan infrastruktur anak-anak yang harus menyediakan campuran kegiatan yang dapat diakses untuk berbagai usia, kemampuan, dan latar belakang. Jaringan tersebut bertujuan untuk meningkatkan perjalanan sehari-hari berupa jalan-jalan yang aman, ramah, dapat dilalui dengan berjalan kaki serta menghubungkan anak-anak dengan alam melalui lingkungan yang hijau dan sehat. Seting jaringan infrastruktur semacam itu ditegaskan juga oleh Thaler dan Sunstein (2008) mampu membawa kepada perilaku sehat anak-anak dan keluarga sejak keluar dari pintu rumah.

\section{b. Kemudahan Aksesibilitas}

Aspek penting yang memungkinkan anak-anak penyandang cacat berjalan dan bersepeda ke sekolah adalah penyediaan infrastruktur yang mudah diakses. Informasi dan panduan rute ke sekolah harus dapat diakses oleh anak-anak juga sekaligus yang berkebutuhan khusus. Dalam panduan tersebut istilah "pejalan kaki" harus memuat pemahaman tentang siswa yang menggunakan alat bantu seperti kursi roda juga. (SRTS Guide, 2015) 


\section{c. Pentingnya Interkoneksi}

Jalan merupakan prasarana pergerakan yang intinya menghubungkan antara satu tempat dengan tempat yang lain. Hubungan bangunan sekolah dengan trotoar dan perlintasan jalan sangat menentukan tingkat kenyamanan dan keselamatan pengalaman pejalan kaki atau pengendara sepeda. Semua elemen saling berhubungan: jalan terhubung ke trotoar dan trotoar terhubung ke gedung. Salah satu implementasi penting adalah larangan meletakkan kendaraan bermotor antara trotoar dan sekolah. Penghalang seperti itu berpotensi menambah titik konflik pada rute berjalan anak.

Bentuk hubungan lain yang perlu dipertimbangkan adalah lokasi relatif sekolah terhadap rumah siswanya. Rute seorang anak ke sekolah harus memiliki jumlah penyeberangan jalan yang memadai dengan memperhatikan batas-batas lokasi sekolah. Pembagian area arah pergerakan pejalan dipertimbangkan dalam penentuan titik-titik penyeberangan jalan. Upaya teknis dan detail tidak selalu memerlukan dana besar untuk mencapai efektifitas dari interkoneksi tersebut. Salah satunya adalah tanda dengan cat yang relatif murah namun membuat perbedaan besar.

Penyelesaian proyek-proyek ini mampu membangun momentum dan menginisiasi minat masyarakat dalam melakukan perbaikan lainnya. Proyek-proyek kecil yang hemat biaya, ketika diimplementasikan bersamaan dengan proyek-proyek yang lebih besar dan lebih mahal, kemungkinan besar akan berdampak lama pada lingkungan binaan dan mengumpulkan minat dan dukungan dari masyarakat. Beberapa perbaikan teknik akan membutuhkan waktu dan komitmen finansial yang besar. Proyek-proyek seperti trotoar dan jembatan baru atau rekonstruksi penyeberangan jalan harus diidentifikasi sejak dini dan maju melalui berbagai tahap yang diperlukan untuk menyelesaikannya. Seiring perbaikan jangka panjang ini dikembangkan, proyek-proyek yang lebih kecil, seperti memasang ramp trotoar yang sesuai standar diimplementasikan untuk membangun momentum dan mempertahankan minat masyarakat dalam menciptakan rute yang aman ke sekolah. Pada akhirnya interkoneksi dari ruang-ruang itu terintegrasi secara luas untuk mewujudkan misi bahwa kota adalah juga tempat untuk anak-anak. (SRTS Guide, 2015)

\section{d. Peran komunitas sekolah untuk keberlanjutan}

Keberlanjutan dari fungsi-fungsi sarana prasarana perlu didukung upaya perawatan yang memadai. Sistem Zonasi membuka peluang keterlibatan masyarakat lokal atau komunitas sekolah untuk berperan serta dalam perawatan, mengingat merekalah sebagian besar yang mendapatkan manfaat keselamatan dan keamanan anak-anak mereka. Peran serta anggota komunitas sangat penting untuk memberikan pertimbangan perbaikan untuk rute ke sekolah. Mereka yang paling memahami masalah, mengidentifikasi masalah dan memberikan solusi secara khusus. Secara kolektif menjadi semacam prinsip-prinsip yang memandu keputusan yang dibuat oleh profesional lokal dan anggota komunitas sekolah dalam rangka meningkatkan lingkungan binaan bagi anak-anak secara aman untuk berjalan dan bersepeda ke sekolah. Beberapa prinsip-prinsip yang akan membantu memandu keputusan sebagai komunitas antara lain adalah:

- Membuat peta rute jalan kaki dan bersepeda menggunakan berbagai alat penilaian dan latihan.

- Mengidentifikasi dan menyusun zona sekolah. 
- Menyediakan dan memelihara fasilitas sepeda dan pejalan kaki di sepanjang rute sekolah termasuk trotoar, fasilitas sepeda di jalan, jalur, trotoar, dan rambu-rambu pejalan kaki.

- Menyediakan penyeberangan jalan yang aman untuk pengendara sepeda dan pejalan kaki.

\section{Atribut Karakter Bermain pada pedestrian anak-anak}

Kekhususan pengguna ruang publik termasuk jalan dapat dikaitkan dengan atribut karakter bermain dari anak-anak. Anak-anak sebagaimana dinyatakan oleh Konvensi Hak Anak memiliki hak publik yang sangat penting untuk mendorong konsep Play Everywhere dan kota ramah anak. Bermain pada dasarnya penting bagi anak-anak untuk membentuk perkembangan kognitif dan fisik, pembelajaran dan kesejahteraan secara menyeluruh (Ginsburg 2007, Kemple et al. 2016). Dalam risetnya Ginsburg menggunakan karakter bermain sebagai pendekatan untuk memulai hidup menuju gaya hidup aktif. Bermain adalah langkah awal pembentukan pola perilaku sehat. Menurutnya bermain adalah ekspresi manusia yang instingtif, tanpa keterpaksaan dan spontan. Melalui bermain manusia belajar memahami dunia. Bermain bisa dalam berbagai bentuk: permainan mulai dari yang ringan hingga yang menantang atau beresiko, dalam rangka pengembangan diri, sekedar kesenangan, memberikan kepuasan atau untuk mencapai prestasi. Kurangnya bermain dapat memiliki dampak signifikan, yang mempengaruhi kesejahteraan secara keseluruhan, pengembangan, penglihatan, alergi dan tingkat aktivitas fisik (NHS Digital 2014).

Anak-anak mencari dan terlibat dalam banyak jenis permainan yang memberi mereka kesempatan untuk belajar, untuk terlibat dengan orang lain, untuk mengalami dan mengeksplorasi. Anak-anak bermain di mana pun dan kapan pun ada peluang untuk melakukannya. Dimulai dari tahap awal pertumbuhan anak bermain eksplorasi sendirian dengan pengasuh mendukung fondasi yang kuat untuk pengembangan. Ketika anak-anak berkembang, bermain sendirian berubah menjadi pola bermain bersama. Bermain dengan orang lain akan mendukung perkembangan kognitif, sosial dan emosional. Tindakan seperti berlari, melompat, memanjat dan menyeimbangkan membantu dengan keterampilan motorik kasar, proprioception dan pemahaman risiko (Kemple et al 2016).

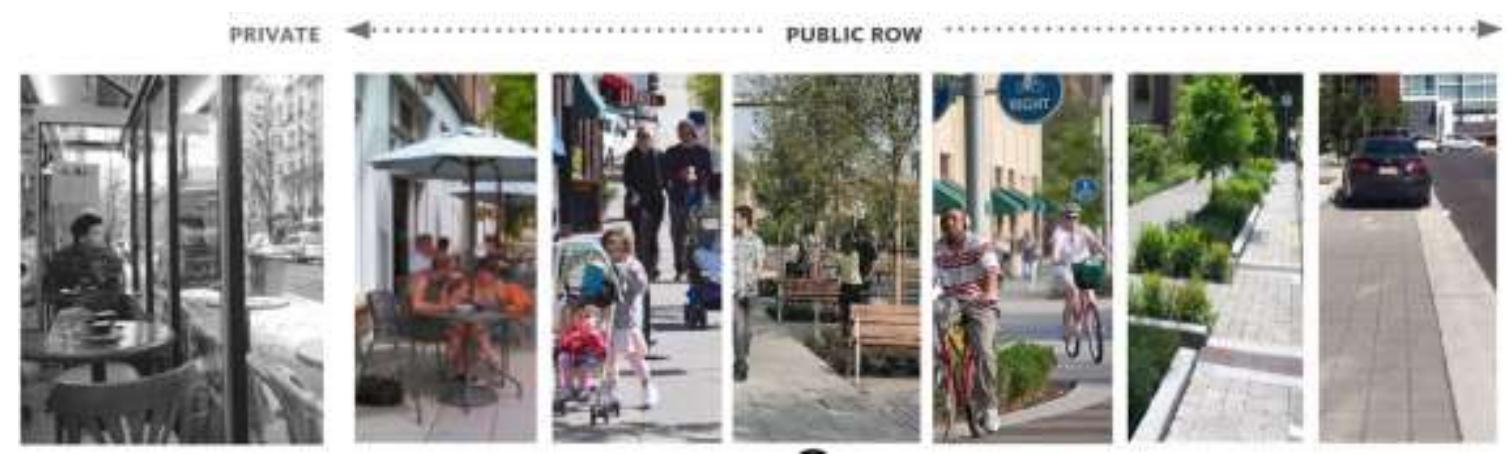

Gambar 1. Pembagian ruang jalan yang sebagian berpeluang untuk menjadi seting bermain anak-anak

Ruang-ruang publik diharapkan mampu mengakomodir karakteristik bermain dan permainan anak-anak tersebut dalam berbagai skala ruang yang mungkin dilalui oleh komunitas 
anak-anak. Jalan, trotoar, perluasan trotoar, jalur, gang, dan juga ruang tangga pada sebuah blok kota selain berfungsi untuk interaksi dan menjalankan bisnis kehidupan sehari-hari juga menjadi ruang bagi anak-anak bersentuhan, belajar dari, dan belajar bagaimana menavigasi dunia orang dewasa. Dengan demikian sebenarnya jalanan, trotoar, dan ruang publik lainnya menawarkan banyak ruang dan peluang untuk bermain. Ruang-ruang jalan, trotoar, dan koneksi antar kampung atau blok dapat diubah menjadi pedestrian way bagi anak-anak sekaligus sebagai seting bermain. Berikut beberapa alternatif seting bermain yang bisa diimplementasikan pada pedestrian way yang sebagian besar disarikan dari The KABOOM sebuah organisasi nirlaba yang berkiprah untuk memerangi kesenjangan dalam ruang bermain anak-anak.sejak tahun 2000an.

\section{a. Seting Jalan}

- Jalan utamanya berfungsi sebagai tempat untuk lalu lintas kendaraan namun bisa memiliki peluang untuk merebut kembali bagian "ruang jalan" di antara trotoar - untuk bermain. Aktifitas menyeberangi penyeberangan dan persimpangan bisa menyenangkan dengan menambahkan visual seperti mural dan elemen dekoratif. Visualisasi tersebut tidak hanya mendorong semangat bermain namun juga bisa memperlambat lalu lintas dan sinyal bahwa anak-anak hidup dan bermain di sepanjang jalan.

- Mengoptimalkan kembali jalur parkir di jalan sebagai parklet, atau ruang publik.

- Mengoptimalkan kembali jalan buntu, jalan buntu, atau jalan dengan lalu lintas rendah lainnya sebagai ruang bermain di dalam jalan selama rentang waktu yang lama yang tidak digunakan oleh lalu lalang kendaraan.

- Mengaktifkan peluang bermain sebagai bagian dari langkah-langkah memperlambat lalu lintas, seperti ekstensi trotoar, bundaran dan lingkaran lalu lintas atau median.

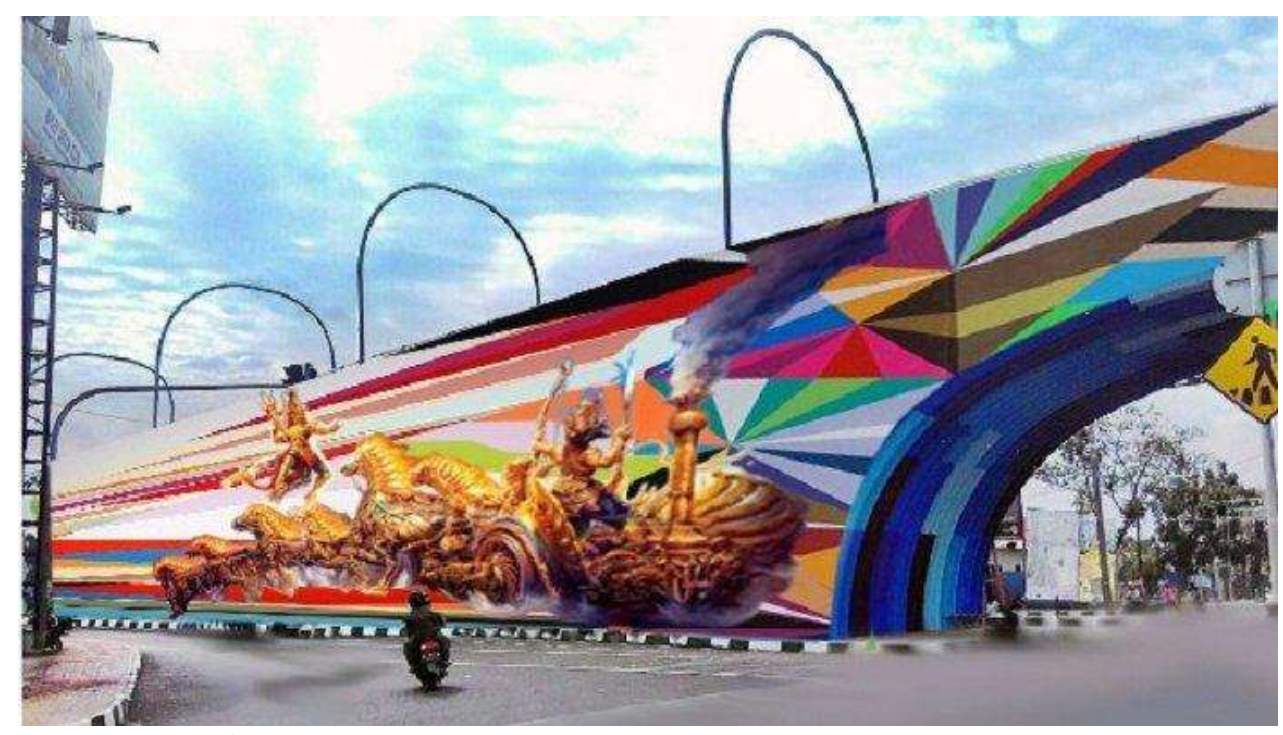

Gambar 2. Mural di dinding bawah jembatan layang

(Sumber: bttps:// cdn2.tstatic.net/solo/foto/bank/ images/desain-mural-flyover-manahan-solo-3.jpg) 
- Mengoptimalkan jalan-jalan bahkan jalan raya utama melalui penutupan sementara jalan semacam program festival jalan raya atau car free day, , pada waktu yang dijadwalkan secara teratur, untuk menciptakan ruang yang besar dan aman untuk berbagai peluang kegiatan bermain.

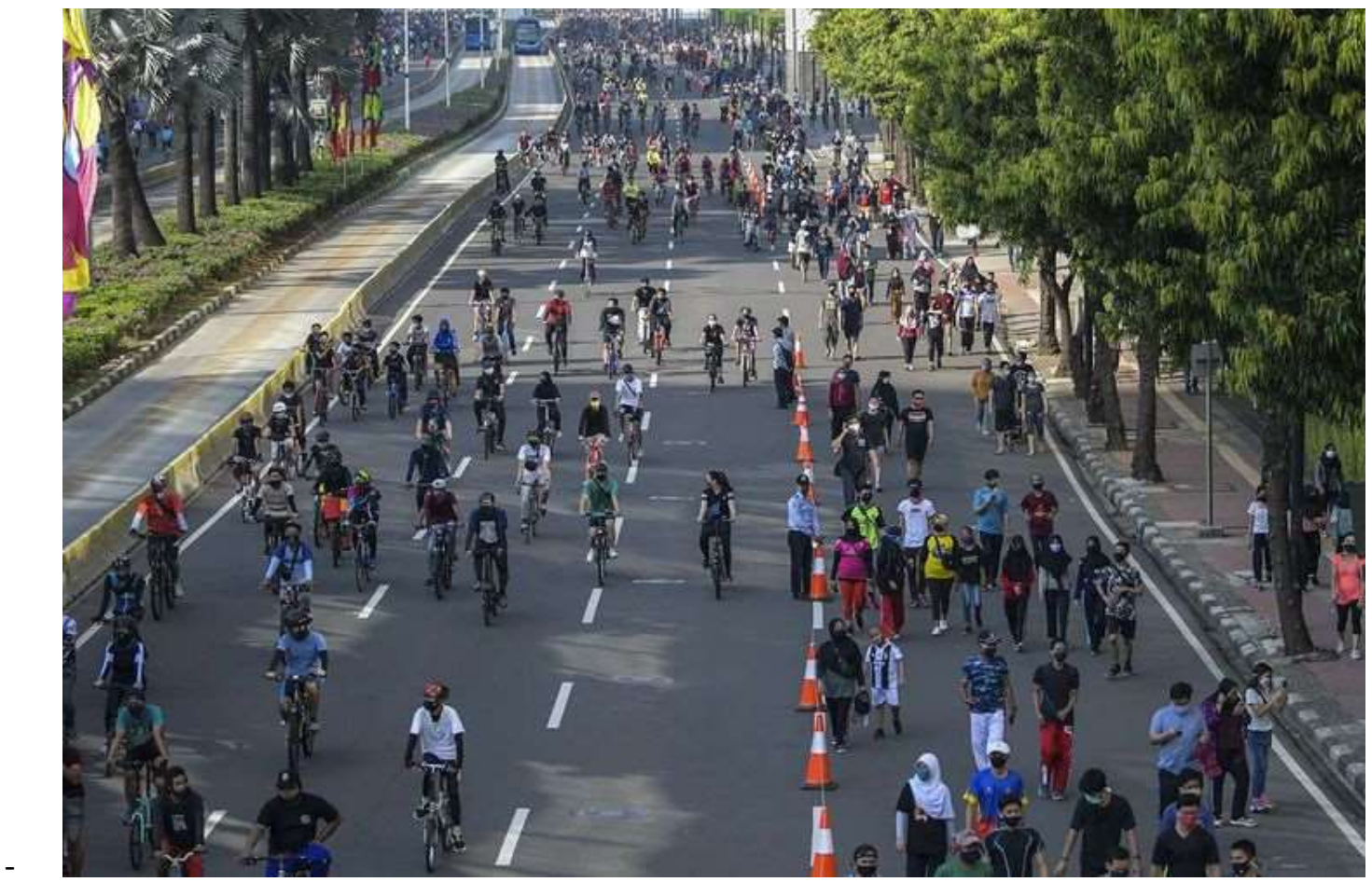

Gambar 3. Suasana Car Free Day di salah satu ruas jalan di Jakarta

(Sumber: https:/ / megapolitan.kompas.com/ read/2020/06/25/21274381/pemkot-jakarta-barat-siapkan-8titik-car-free-day-ini-daftarnya?page=all)

\section{b. Seting di luar trotoar}

Setiap infrastruktur jalan terdiri dari bentangan jalanan, dari trotoar sendiri, tepi bentangan jalan yang berbatasan dengan jalan dan bangunan yang berpeluang seting pengalaman bermain. Berikut beberapa alternatif visualisasi yang bisa diterapkan.

- Meramaikan area pejalan kaki melalui zona trotoar dengan mural yang dicat dan permainan di trotoar, atau menyediakan tempat bagi anak-anak untuk membuat seni kapur sendiri. Kelebihan ruang ada di sepanjang trotoar yang sangat luas, sebagian dari ruang trotoar dapat dikhususkan untuk bermain, sambil tetap mengakomodasi perjalanan pejalan kaki.

- Memasukkan berbagai peluang permainan ke dalam zona tanam dan furnitur yang memisahkan trotoar utama dari trotoar di sepanjang jalan. Terletak di luar zona di mana pejalan kaki bepergian, daerah-daerah ini sering termasuk pohon rindang dan mungkin cukup lebar untuk mengakomodasi tempat duduk dan perabotan jalan lainnya. 
- Jika terdapat setback dari trotoar sangat dalam, ruang antara trotoar dan bagian depan bangunan dapat mengakomodasi instalasi permainan skala yang lebih besar. Dalam konteks lain, terutama di sepanjang lingkungan jalan utama perkotaan di mana bangunan terletak dekat dengan jalan, hanya ruang sempit yang mungkin ada di antara bagian depan bangunan. Meskipun sempit, ruang-ruang ini seringkali cukup luas untuk menampung instalasi permainan kecil, tanpa menghalangi perjalanan pejalan kaki.

- Memasang tanda-tanda petunjuk jalan dan informasi yang mengundang anak-anak untuk bermain, memperkuat suasana jalanan yang menyenangkan, mengarahkan keluarga untuk bermain peluang dan memberi sinyal kepada orang dewasa dan melewati pengendara bahwa "anak-anak boleh bermain di sini."

- Animasi fasad bangunan dan jendela dengan mural, permainan, dan elemen menyenangkan lainnya yang dilukis atau dilampirkan pada fasad

- Menciptakan furnitur jalanan yang menyenangkan yang bisa menambah imajinasi jalan-jalan, sesuai sudut pandangan mata anak-anak. Misalnya, mengubah tong sampah lebih menarik dengan dilukis, atau memasang bangku dan rak sepeda dengan desain yang menyenangkan.

- Menciptakan seting bermain di trotoar yang terintegrasi dengan halte bus sekolah sehingga memberikan anak-anak pengalaman dan cara yang aman dan menyenangkan untuk sampai ke sekolah.

\section{c. Seting di antara ruang}

Di sepanjang jalan-jalan kota, banyak "ruang sisa" bangunan dan infrastruktur yang terabaikan namun menawarkan potensi yang belum dimanfaatkan untuk bermain. Beberapa ruang seperti fasad bangunan kosong dan tidak berjendela, dinding dan pagar, tidak menarik atau diabaikan. Ruang lainnya adalah ruang di bawah jembatan, dapat berfungsi sebagai hambatan fisik dan psikologis di antara lingkungan karena letaknya yang terpencil, tidak menarik dan tidak aman. Pada ruang-ruang tersebut dapat dilakukan antara lain:

- Makeover kreatif dan menyenangkan dari ruang-ruang ini tersebut menjadi lebih mengundang, menghilangkan penghalang yang ada di lingkungan buatan tersebut. Ini juga dapat mengubah ruang "pembagi" antara lingkungan menjadi tempat berkumpul yang menyatukan masyarakat.

- Bayangkan kembali dinding kosong dan tidak berjendela sebagai kanvas masyarakat atau mural penuh dengan permainan, imajinasi, atau narasi lingkungan.

\section{d. Seting di bagian tengah blok}

Di beberapa blok kota terdapat berbagai lorong tengah blok, termasuk lorong servis, jalur dan tangga tengah blok, melayani fungsi-fungsi penting untuk utilitas dan layanan kota, yang menghubungkan orang dan kendaraan dengan lebih efisien ke tujuan mereka. Ruang-ruang ini sering menjadi sebagian terabaikan, tersembunyi dari pandangan publik karena tidak menyenangkan untuk dinavigasi. Namun dengan beberapa imajinasi dan visualisasi ruang-ruang tengah blok ini memiliki potensi untuk menyatukan blok-blok kota menjadi lebih berfungsi sebagai tempat berkumpulnya komunitas. Dengan demikian diharapkan akan menumbuhkan ruang-ruang bagi 
anak-anak untuk dapat bermain tanpa bersentuhan dengan lalu lintas dari jalan-jalan yang berdekatan dan rute yang menyenangkan untuk berjalan dan bersepeda. Beberapa cara memanfaatkan lorong-lorong pertengahan blok kota bisa berupa:

- Mengaktifkan gang blok tengah dengan cahaya, cat, game atau peralatan bermain. Menutup sementara atau secara permanen gang untuk lalu lintas supaya bisa berfungsi sebagai ruang bermain atau tempat untuk acara lingkungan.

- Gang juga bisa diubah secara permanen menjadi jalan bersama yang memungkinkan akses kendaraan, tetapi memprioritaskan berjalan kaki dan bersepeda.

- Menggabungkan wahana bermain mini atau yang menyenangkan di sepanjang jalur tengah blok menjadi lebih menarik untuk jalan pintas antar tujuan.

- Menghidupkan tangga yang panjang dan melelahkan dengan seni dan imajinasi untuk membuat pendakian lebih menyenangkan dan tidak terasa berat.

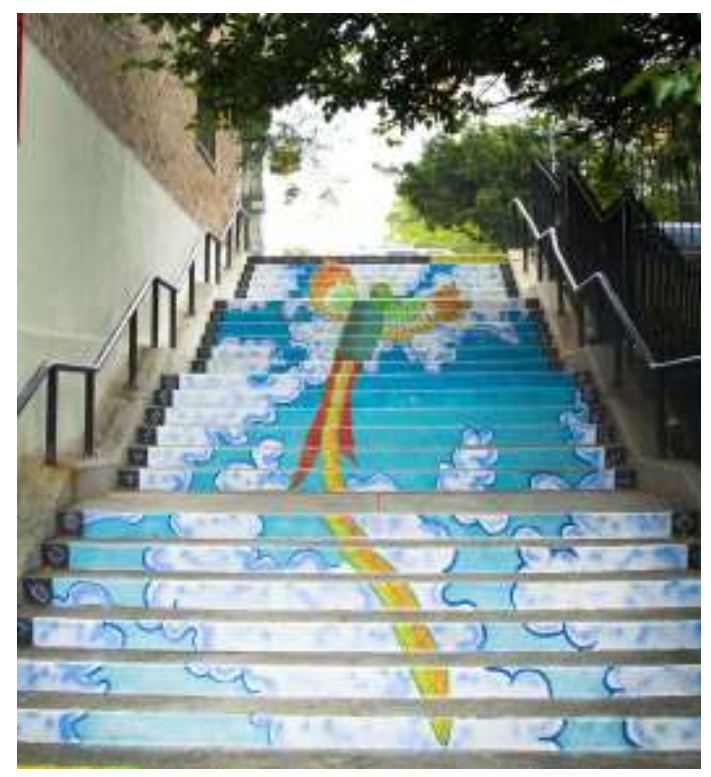

Gambar 2. Mural pada tangga blok permukiman/kampung

(sumber: https://kaboom.org/playbook/design-guides/streets-sidewalks)

\section{REFERENSI}

Sistem zoning yang menjadi kebijakan pemerintah Indonesia diyakini memberi dampak positif bagi perkembangan sektor perkotaan. Kebijakan tersebut dapat menjadi momentum dalam mewujudkan kota ramah anak yang salah satunya dapat diukur dengan eksistensi fungsi ruang-ruang bagi pedestrian anak-anak. Tulisan ini diharapkan menjadi wacana dalam pengembangan dan perencanaan fasilitas bagi pedestrian anak-anak. Aspek khusus perencanaan fasilitas bagi pedestrian anak-anak salah satunya mengakomodir atribut ketersediaan ruang dan fasilitas dan atribut karakter bermain anak-anak. Atribut ketersediaan ruang harus dipahami sebagai sebuah jaringan utuh dalam sebuah rute yang aman dan nyaman bagi anak-anak untuk berjalan kaki dari rumah menuju sekolah. Unsur-unsur teknis dalam atribut ini adalah meliputi (1) Infrastruktur di dalam zona sekolah dan 
lingkungannya, (2) Kemudahan aksesibilitas, (3) Pentingnya interkoneksi dalam rute, dan juga tidak kalah pentingnya (4) Peran komunitas sekolah untuk keberlanjutan. Sementara dalam mewujudkan perencanaan dan desainnya diharapkan mampu mengakomodir karakter anak-anak yang didominasi aktifitas bermain. Karakter aktifitas bermain dan permainan anak-anak tersebut diimplementasikan melalui elemen-elemen stimulus bermain dan kreatifitas dalam berbagai skala ruang yang mungkin dilalui oleh anak-anak. Komponen jalan berupa jalan itu sendiri, trotoar, perluasan trotoar, jalur, gang, dan juga ruang tangga pada sebuah kawasan kota bisa difungsikan selain untuk interaksi dan kehidupan sehari-hari juga menjadi ruang bagi anak-anak untuk belajar dari, dan belajar bagaimana menavigasi dunia orang dewasa. Dengan demikian kebijakan sistem zoning mampu menjangkau perilaku kehidupan anak-anak dalam proses belajar dan berkehidupan sebagaimana mestinya.

\section{REFERENSI}

Arup. 2017. Cities alive: designing for urban childhoods. London: Arup.

Brown C. , Lannoy A., McCracken D., Gill T. , Grant M., Wright H. \& Williams S. 2019. Special issue: child-friendly cities, Cities \& Health,3:1-2, 1-7, doi: 10.1080/23748834.2019.1682836

Gehl Institute. 2017. Space to grow: 10 principles that support healthy, happy families in a playful, friendly city. https://gehlinstitute.org/wp-content/uploads/2018/04/GehlInstitute_SpaceTo Grow_single_pages.pd

Ginsburg, K.R., Jan 2007. The importance of play in promoting healthy child development and maintaining strong parent-child bonds. Pediatrics, 119 (1), 182-191. doi:10.1542/peds.20062697

Kaboom. 2020. Street and Sidewalks. https://kaboom.org/playbook/design-guides/streets-sidewalks

Kemple, K.M., et al., 2016. The power of outdoor play and play in natural environments. Childhood education, 92 (6), 446-454. doi:10.1080/00094056.2016.1251793

Nugroho, Yudhistira Adi . 2018. Keamanan dan Kenyaman Trotoar di Taman Tingkir, Kota Salatiga. Mintakat: Jurnal Arsitektur, Vol 19, No 1 (2018). https://doi.org/10.26905/mintakat.v19i1.1440

NHS Digital, 2014. Health survey England 2012. https://digital.nhs.uk/data-andinformation/publications/statistical/health-survey-for-england/healthsurvey-for-england-2012

Mungkasa OM. 2017. Grand Design Jakarta Menuju Kota Layak Anak.

SRTS Program. 2015. Safe Routes to School http://guide.saferoutesinfo.org/index.cfm

UNHR. 1990. Convention on the Rights of the Child. United Nation of Human Right.

Thaler, R.H. and Sunstein, C.R., 2008. Nudge: improving decisions about health, wealth, and happiness.

UNICEF, 2012. The state of the world's children 2012: children in an urban world.

UNICEF, 2018. Advantage or paradox? The challenge for children and young people of growing up urban. 